\title{
Pendekatan Diagnostik Serologik dan Pelacak Antigen Salmonella typhi
}

\author{
Sylvia Retnosari, Alan R Tumbelaka
}

\begin{abstract}
Biakan empedu merupakan baku emas untuk menegakkan diagnosis demam tifoid namun memerlukan waktu 5-7 hari untuk mendapatkan hasilnya. Kegunaan pemeriksaan serologi Widal sampai saat ini masih kontroversial. Hal lain yang patut diperhatikan adalah belum ditetapkannya nilai cut off titer antibodi dalam uji Widal khususnya pada demam tifoid anak. Oleh karena itu perlu adanya suatu teknik pemeriksaan penunjang lain yang ideal (cepat, sensitif, spesifik dan murah) sebagai alternatif uji diagnostik demam tifoid. Diagnosis demam tifoid pada anak kadangkala sulit ditegakkan atas dasar gambaran klinis saja, oleh karena gambaran klinis penyakit ini amat bervariasi dan umumnya tidak khas, oleh karena itu pemeriksaan laboratorium klinik yang dapat diandalkan sangat diperlukan. Secara garis besar pemeriksaan laboratorium untuk menunjang diagnosis demam tifoid adalah: (1) isolasi kuman S. typhi dari biakan spesimen pasien, (2) uji serologi untuk mendeteksi antibodi spesifik terhadap $S$. typhi dan mendeteksi adanya antigen spesifik dari S. typhi, dan (3) pemeriksaan melacak adanya DNA S. typhi. Telah banyak usaha yang dilakukan untuk mendapatkan pemeriksaan laboratorium yang andal sebagai penunjang diagnosis demam tifoid. Beberapa pemeriksaan uji laboratorium tersebut masing-masing memiliki keunggulan dan kelemahan tersendiri. Di Indonesia sarana penunjang diagnosis demam tifoid yang ideal harus mempunyai sifat andal, dapat memberikan diagnosis yang cepat, praktis dan tentu tidak mahal. Untuk tujuan ini, perkembangan pemeriksaan laboratorium diagnostik terhadap demam tifoid ke arah tehnik dot enzyme immunoassay, baik untuk keperluan penentuan antigen maupun antibodi terhadap kuman $S$. typhi kiranya akan dapat memenuhi persyaratan tersebut di atas.
\end{abstract}

Kata kunci: Salmonella typhi- ELISA - typhi dot.

D emam tifoid adalah suatu penyakit sistemik yang disebabkan oleh kuman Salmonella typhi. Di Indonesia demam tifoid merupakan penyakit endemik dengan angka kejadian masih tinggi serta merupakan masalah kesehatan masyarakat

* Peserta program Studi Ilmu Kesehatan Anak FK-UI / RSCM Jakarta (Dr. Sylvia Retnosari),** Bagian Ilmu Kesehatan Anak FKUI-RSCM, Jakarta (Dr. Alan R Tumbelaka Sp.A(K)).

Alamat korespondensi:

Dr. Sylvia Retnosari, Dr. Alan R Tumbelaka Sp.A(K) Bagian Ilmu Kesehatan Anak FKUI-RSCM, Jakarta Telpon: (021) 314 8610. Fax.: (021) 3913982. yang berkaitan dengan kesehatan lingkungan dan sanitasi yang buruk. ${ }^{1-3}$ Meskipun penyakit ini tidak terbatas pada umur tertentu, namun angka kejadian cukup tinggi pada anak umur di atas 5 tahun. Gejala klinis demam tifoid pada anak umumnya lebih ringan dibandingkan orang dewasa, namun dapat terjadi komplikasi dan kematian. ${ }^{4}$ Gambaran klinis pada anak seringkali tidak khas bahkan hanya demam, sehingga terjadi kesulitan untuk menegakkan diagnosis demam tifoid. Oleh karena perlu ditunjang dengan pemeriksaan laboratorium yang andal untuk menegakkan diagnosis. ${ }^{2}$ Diagnosis demam tifoid dengan biakan kuman merupakan diagnosis pasti, 
namun identifikasi S. typhi memerlukan waktu 5-7 hari. Biakan darah sering positif di awal penyakit, sedangkan biakan urin dan tinja positif setelah septikemia sekunder. Spesimen lain untuk isolasi kuman melalui biakan adalah sumsum tulang, cairan empedu dan rose spots. ${ }^{2}$ Pemeriksaan uji serologi Widal kegunaannya banyak diragukan, dan interpretasi harus dilakukan dengan hati-hati dengan mempertimbangkan sensitivitas, spesifisitas serta perkiraan untuk uji laboratorium dan populasi setempat. ${ }^{4,5,6}$ Akhir-akhir ini telah dilakukan penelitian uji Dot Enzyme Immunoassay (Dot EIA), yakni metoda untuk mendeteksi antibodi terhadap antigen spesifik S. typhi. Antigen (protein) spesifik hanya dimiliki kuman S.typhi ini memberikan peluang untuk pengembangan penelitian uji serodiagnostik pada demam tifoid. ${ }^{7,8}$ Kemajuan di bidang biomolekular telah sampai pada penelitian mendeteksi DNA/RNA (asam nukleat) kuman $S$. typhi dalam darah dengan tehnik hibridisasi asam nukleat dengan metoda polymerase chain reaction (PCR). ${ }^{9,10}$ Namun sampai saat ini penggunaannya masih terbatas dalam laboratorium penelitian. Berdasarkan kenyataan tersebut perlu terus dipelajari kemajuan di bidang diagnosis laboratorium penyakit infeksi khususnya demam tifoid. Dengan harapan dapat ditetapkan pendekatan diagnostik demam tifoid yang lebih cepat, sensitif, spesifik dan murah.

\section{Morfologi dan Klasifikasi}

Salmonela merupakan Gram negatif, motile, batang, aerobik, tidak menghasilkan spora, berflagela, berkapsul, termasuk famili Enterobacteriaceae. Mempunyai karakteristik fermentasi terhadap glukosa dan manosa tapi tidak terhadap laktosa atau sukrosa. Kuman ini tahan pada pembekuan dalam air jangka waktu lama, namun mati pada pemanasan suhu $54,4^{\circ} \mathrm{C}$ selama satu jam dan $60^{\circ} \mathrm{C}$ selama 15 menit. ${ }^{4,7,11}$ Terdapat tiga jenis Salmonela yaitu Salmonela typhi (mempunyai 1 serotipe), Salmonela enteritidis (lebih dari 1500 serotipe), dan Salmonela choleraesuis (1 serotipe). ${ }^{4,7,11}$ Salmonela mempunyai empat komponen antigen, yakni antigen $\mathrm{H}$ (flagela), antigen $\mathrm{O}$ (dinding sel/lipopoli sakarida), yang terdiri dari lebih dari 60 jenis antigen, antigen $\mathrm{Vi} /$ antigen kapsul, dan protein membran luar (outer membrane protein). ${ }^{12}$

\section{Diagnosis Demam Tifoid}

Mengingat gambaran klinis demam tifoid pada anak tidak khas yang mengakibatkan sering terjadi kesulitan dalam menegakkan diagnosis bila hanya berdasarkan gambaran klinis, maka perlu ditunjang dengan pemeriksaan laboratorium yang dapat diandalkan. ${ }^{6}$ Sarana laboratorium untuk membantu menegakkan diagnosis demam tifoid secara garis besar digolongkan dalam tiga kelompok yaitu: (1) isolasi kuman penyebab demam tifoid, Salmonela typhi, melalui biakan kuman dari spesimen seperti darah, sumsum tulang, urin, tinja, dan cairan duodenum, (2) uji serologi untuk mendeteksi antibodi terhadap antigen S. typhi dan menentukan adanya antigen spesifik dari S. typhi, serta (3) pemeriksaan pelacak DNA kuman S. typhi.

\section{Biakan S. typhi}

Diagnosis pasti demam tifoid dapat ditegakkan bila ditemukan kuman Salmonela typhi dalam darah, urin, tinja, sumsum tulang, cairan duodenum atau dari rose spots. Berkaitan dengan patogenesis penyakit, maka kuman lebih mudah ditemukan di dalam darah dan sumsum tulang di awal penyakit, sedangkan pada stadium berikutnya di dalam urin dan tinja. Biakan darah terhadap Salmonela tergantung dari sat pengambilan pada perjalanan penyakit. Beberapa peneliti melaporkan biakan darah positif $70-90 \%$ dari penderita pada minggu pertama sakit, dan positif $50 \%$ pada akhir minggu ketiga. ${ }^{13}$ Kuman dalam tinja ditemukan meningkat dari minggu pertama (10-15\%) hingga minggu ketiga (75\%) dan turun secara perlahan. Biakan urin positif setelah minggu pertama. ${ }^{13}$ Biakan sumsum tulang sering tetap positif selama perjalanan penyakit dan menghilang pada fase penyembuhan. ${ }^{11}$ Hoffman dkk, melaporkan dalam penelitiannya di RS. Penyakit infeksi pada tahun 1986 di Jakarta bahwa biakan sumsum tulang lebih sensitif (92\%) secara bermakna dibandingkan biakan darah (62\%), biakan klot streptokinase $(51 \%)$, dan biakan usap dubur (56\%).

Gilman dkk, ${ }^{14}$ melaporkan dalam penelitiannya terhadap 62 pasien dengan demam tifoid yang sebagian besar dari mereka telah mendapat terapi, bahwa isolasi kuman $S$. typhi positif dari biakan sumsum tulang pada 56 pasien (90\%); sedangkan dari biakan darah, tinja dan urin masing-masing positif pada 25 pasien (40\%), 
23 pasien (37\%) dan 4 pasien (7\%). Kuman S. typhi berhasil diisolasi pada 24 (63\%) dari 38 pasien biakan rose spots. Meskipun metoda biakan/isolasi bakteri Salmonela typhi sebenarnya sangat menentukan diagnostik, namun terdapat beberapa kendala yaitu: (1) identifikasi kuman S. typhi di laboratorium klinik memerlukan waktu 5-7 hari, (2) biakan bakteri sulit dilakukan di daerah yang tidak memiliki sarana laboratorium lengkap. ${ }^{4}$

\section{Uji Serologi}

Pengukuran kadar antibodi terhadap kuman penyebab infeksi dalam serum atau darah manusia dapat dipakai untuk menunjang diagnosis infeksi oleh mikroorganisme bersangkutan. ${ }^{15}$ Beberapa jenis uji serologi infeksi Salmonela diuraikan di bawah ini.

\section{Uji Serologi Widal}

Uji serologi standar dan rutin untuk diagnosis demam tifoid adalah uji Widal. Uji ini telah digunakan sejak tahun 1896. Prinsip uji Widal adalah serum pasien dengan pengenceran berbeda-beda ditambah antigen dalam jumlah sama. Jika dalam serum terdapat antibodi maka akan terjadi aglutinasi. Pengenceran tertinggi yang masih menimbulkan aglutinasi menunjukkan titer antibodi dalam serum. ${ }^{4,5,13}$ Uji serologi Widal sebenarnya tidak spesifik oleh karena beberapa hal, yakni (1) semua Salmonela dalam grup D (kelompok Salmonella typhi) memiliki antigen $\mathrm{O}$ yang sama yakni nomor 9 dan 12, namun perlu diingat bahwa antigen O nomor 12 dimiliki pula oleh Salmonela grup A dan $B$ (yang lebih dikenal sebagai paratyphi A dan paratyphi B), (2) semua Salmonela grup D memiliki antigen $\mathrm{H}$ d fase 1 seperti S. typhi, dan (3) titer antibodi H masih tinggi untuk jangka waktu lama setelah infeksi atau imunisasi. ${ }^{13,16}$

Sensitivitas uji Widal juga rendah, sebab kultur positif yang bermakna pada pasien tidak selalu diikuti dengan terdeteksinya antibodi dan pada pasien yang mempunyai antibodi pada umumnya titer meningkat sebelum terjadinya onset penyakit. Sehingga keadaan ini menyulitkan untuk memperlihatkan kenaikan titer 4 kali lipat. ${ }^{16}$ Kelemahan lain dari uji Widal adalah antibodi tidak muncul di awal penyakit, sifat antibodi sering bervariasi dan sering tidak ada kaitannya dengan gambaran klinis penyakit, dan dalam jumlah yang cukup besar (15\% atau lebih) tidak terjadi kenaikan titer O bermakna. ${ }^{16}$

Mengingat hal-hal tersebut di atas. meskipun uji serologi Widal sebagai alat penunjang diagnosis demam tifoid telah luas digunakan di seluruh dunia, namun manfaatnya masih menjadi perdebatan. ${ }^{7}$ Sampai saat ini pemeriksaan serologi Widal sulit dipakai sebagai pegangan karena belum ada kesepakatan akan nilai standar aglutinasi (cut offpoint). Untuk mencari standar titer uji serologi Widal seharusnya ditentukan titer dasar (base line titer) pada anak sehat di populasi. Beberapa penulis telah melaporkan nilai standar aglutinasi yang berbeda-beda untuk diagnosis demam tifoid dengan uji Widal, oleh karena nilai sensitivitas, spesifisitas dan perkiraan uji ini sangat berbeda antar laboratorium klinik. Nilai cut-offuji widal yang dipakai saat ini berdasarkan penelitian pada tahun 60-an, maka dengan adanya kemajuan sanitasi dan pendidikan kesehatan, data dasar perlu diperbaharui. Dengan demikian interpretasi hasil uji Widal harus dilakukan sangat hati-hati karena banyak faktor yang berpengaruh terhadap hasil uji ini..$^{8,20}$

\section{Uji ELISA}

Uji ELISA (enzyme linkage immunosorbent assay) untuk melacak antibodi terhadap antigen S.typhi akhir-akhir ini mulai banyak dipakai. Antibodi yang dilacak dengan uji ini tergantung dari jenis antigen yang dipakai. ${ }^{17}$

\section{Dot Enzyme Immunosorbent Assay (Dot EIA)}

Salah satu uji serologi untuk melacak antibodi spesifik terhadap $S$. typhi yang sedang dikembangkan adalah Dot Enzyme Immunosorbent Assay (Dot EIA). 7,18,19 Beberapa penelitian terbaru terhadap kuman S. typhi melaporkan adanya protein spesifik yang berada di membran luar kuman atau outer membrane protein (OMP) untuk dijadikan antigen dalam sistem pendeteksi antibodi IgM S. typhi. ${ }^{7,18,19,20}$ Ismail $\mathrm{dkk}^{7,18}$ berhasil mengembangkan penelitian penggunaan metoda Dot EIA ini untuk mendeteksi antibodi terhadap S. typhi. Uji ini dikembangkan berdasarkan hasil penelitian sebelumnya, bahwa mereka mendapat- 
kan OMP kuman $S$. typhi yang mempunyai berat molekul $50 \mathrm{kDa}$ ternyata spesifik hanya didapatkan dari serum pasien demam tifoid (berdasarkan biakan kuman positif dari spesimen penderita). Protein alamiah ini terletak pada membran luar kuman Salmonella dan bukan merupakan antigen $\mathrm{Vi}$ (antigen kapsul), $\mathrm{H}$ (flagela) atau $\mathrm{O}$ (dinding sel/lipopolisakarida). Protein spesifik yang hanya dimiliki oleh kuman $S$. typhi ini memberikan peluang untuk pemeriksaan uji serodiagnostik pada penderita demam tifoid. ${ }^{7,8}$ Metoda ini lebih maju jika dibandingkan dengan sistem immunoblotting. Pada sistem deteksi ini antigen yang digunakan terbatas pada antigen OMP dengan berat molekul $50 \mathrm{kDa}$, sedangkan pada immunoblotting masih menggunakan semua fraksi OMP. ${ }^{20}$

Pada penelitian lain, Ismail $\mathrm{dkk},{ }^{19}$ melaporkan penelitian terhadap 109 kasus demam tifoid bahwa spesifisitas uji ini $75 \%$, 25\% positif terhadap kultur darah negatif. Dilaporkan pula bahwa uji dot EIA ini memiliki sensitivitas $95-100 \%$ (pada penderita demam tifoid dengan kultur Salmonella typhi positif) dengan sekali pemeriksaan dan 100\% dengan pemeriksaan ulang serum. Ini berarti setiap kali kultur darah positif, maka uji ini akan memberikan nilai $100 \%$ positif pula. Uji dot EIA tidak ada reaksi silang dengan salmonellosis bukan tifoid jika dibandingkan dengan Widal. Dengan demikian jika dibandingkan dengan uji Widal, sensitivitas uji dot EIA lebih tinggi oleh karena kultur positif yang bermakna tidak selalu diikuti dengan uji Widal positif. ${ }^{6,18}$ Dalam penelitian lain dilaporkan sensitivitas uji Widal adalah $60 \%$ bahkan pernah dilaporkan kurang dari $60 \% .{ }^{15}$

Saat ini metoda uji dot EIA telah diluncurkan sebagai produk yang disebut Typhidot. Dalam kit Typhidot telah tersedia beberapa material dan reagen yang telah siap untuk diuji di laboratorium klinik. ${ }^{18}$ Beberapa keuntungan metoda ini adalah memberikan sensitivitas dan spesifisitas yang tinggi, sedikit kemungkinan terjadinya reaksi silang dengan penyakit demam lain, murah (karena menggunakan antigen dan membran nitroselulosa sedikit), tidak menggunakan alat yang khusus sehingga dapat digunakan luas di fasilitas kesehatan sederhana yang belum tersedia biakan kuman. Keuntungan lain antigen pada membran lempengan nitroselulosa yang belum ditandai dan diblok dapat tetap stabil selama 6 bulan jika disimpan pada suhu $4^{\circ} \mathrm{C}$ dan bila hasil didapatkan dalam waktu 3 jam setelah penerimaan serum pasien. ${ }^{18}$

\section{Uji Serologi Pemeriksaan Antigen}

Pelacakan antigen spesifik dari S. typhi dalam spesimen pasien demam tifoid (darah atau urin) secara teoritis dapat memberikan diagnosis secara dini dan cepat. Wong dkk. ${ }^{21}$ menggunakan tehnik aglutinasi lateks yang dilapisi antibodi monoklonal IgM Salmonella 09 dan dapat memperoleh hasil tes dalam waktu satu menit dengan sensitivitas dan spesifisitas masingmasing sebesar $87,5-100 \%$ dan 97,8-100\%. Uji ELISA yang sering dipakai untuk mendeteksi adanya antigen S. typhi dalam spesimen klinis adalah double antibody sandwich ELISA. Chaicumpa ${ }^{22}$ dengan tehnik yang sama mendapatkan sensitivitas $65 \%$ dan spesifisitas $100 \%$ pada urin penderita. Ia melaporkan bahwa dengan dot enzyme immunoassay untuk melacak adanya antigen S.typhi dalam urin dengan menggunakan antibodi monoklonal terhadap grup $\mathrm{O}$ Salmonella antigen 9 mendapatkan sensitivitas $85 \%$. Sadallah ${ }^{23}$ menggunakan antibodi monoklonal terhadap antigen flagela d-H untuk deteksi antigen $S$. typhi dalam serum pasien dan mendapatkan sensitivitas sebesar $96 \%$ dan spesifisitas $92 \%$.

Dari data tersebut di atas dapat disimpulkan bahwa masih terdapat variasi nilai yang luas baik sensitivitas maupun spesifisitas dari deteksi antigen spesifik $S$. typhi oleh karena tergantung dari beberapa hal, yakni jenis antigen, jenis spesimen yang diperiksa, tehnik yang dipakai untuk melacak antigen tersebut, jenis antibodi yang digunakan dalam tes (poliklonal atau monoklonal), dan waktu pengambilan spesimen (stadium dini atau lanjut dalam perjalanan penyakit). ${ }^{24}$

\section{Hibridisasi Asam Nukleat}

Metoda lain untuk identifikasi kuman S. typhi yang akurat adalah mendeteksi DNA (asam nukleat) kuman S. typhi dalam darah dengan tehnik hibridisasi asam nukleat atau amplifikasi DNA dengan cara polymerase chain reaction (PCR). ${ }^{7}$

Dasar spesifisitas reaksi hibridisasi adalah kemampuan asam nukleat utas/rantai tunggal untuk mendeteksi dan membentuk ikatan hidrogen (hibridisasi) dengan asam nukleat utas tunggal yang mengandung urutan asam nukleat padanannya. Reaksi hibridisasi merupakan reaksi kinetik yang efisien dan dapat mendeteksi sejumlah sangat kecil asam nukleat kuman dalam waktu yang sangat 
pendek. Pada sistem hibridisasi ini, sebuah molekul asam nukleat yang sudah diketahui spesifisitasnya (DNA probe) digunakan untuk mendeteksi ada atau tidaknya urutan asam nukleat yang sepadan dari target DNA (kuman). Meskipun DNA probe memiliki spesifisitas tinggi, pemeriksaan ini tidak cukup sensitif untuk mendeteksi jumlah kuman dalam darah yang sangat rendah, misalnya 10-15 S. typhi/ml darah dari pasien demam tifoid. ${ }^{9,10,25}$ Dengan kemajuan teknologi di bidang molekular, target DNA telah dapat diperbanyak terlebih dahulu sebelum dilakukan hibridisasi. Penggandaan target DNA dilakukan dengan tehnik PCR menggunakan enzyme DNA polimerase. $^{10,25}$

Cara ini dapat melacak DNA S. typhi sampai sekecil satu pikogram namun usaha untuk melacak DNA dari spesimen klinis masih belum memberikan hasil yang memuaskan. ${ }^{10,25}$

\section{Daftar Pustaka}

1. Chaudhry R, Ray K, Kumar R. Polymerase chain reaction for the detection of Salmonella typhi in the blood of patients of typhoid fever. Dalam : Sarasombath $S$, Senawang S, penyunting. Second Asia-Pasific symposium on typhoid fever and other salmonellosis. Thailand: SEAMEO Regional Tropical Medicine and Public Health Network, 1995; h.244-5.

2. Kusum M, Santhadvanich R, Phaisomboon S. Laborator surveillance of S. typhi infection after suspension of typhoid vaccination in Thailand. Dalam : Sarasombath S, Senawang S, penyunting. Second Asia-Pasific symposium on Tropical Medicine and Public Health Network, 1995;h.272-4.

3. Simanjuntak $\mathrm{CH}$. Demam tifoid, epidemiologi dan perkembangan penelitiannya. Cermin Dunia Kedokteran $1993 ; 83: 52-4$

4. Mahle WT, Levine MM. Salmonella typhi infection in children younger than five years of age. Pediatr Infect Dis J 1993; 12:627-31.

5. Nelwan RHH. Skor nilai ramal alat bantu diagnostik demam tifoid. Disampaikan pada Simposium perkembangan baru dalam diagnostik dan pencegahan (imunisasi) demam tifoid, Jakarta, 20 September 1995.

6. Chow CB, Wang PS, Cheung M, et al. Diagnostic value of widal test in childhood typhoid fever. Pediatr Infect Dis J 1987;6:914-7.

7. Ismail A, Kader ZK, Ong KH. Development of dot enzyme immunosorbent assay for the rapid diagnosis of typhoid fever. Dalam : Pang T, Koh CL, Puthucheary SD, penyunting. Typhoid fever strategies for the 90's. Singapore : World Scientific Publishing, 1991;h.2016.
8. Rodriguez AV, Santana FJ, Puente JL, et al. Salmonella typhi outer membrane proteins in the diagnosis of typhoid fever. Dalam : Pang T, Koh CL, Puthucheary SD, penyunting. Typhoid fever strategies for the 90's.Singapore: World scientific, 1991;h.216-20.

9. Loho T. Beberapa perkembangan pemeriksaan laboratorium untuk penanganan penyakit infeksi, khususnya demam tifoid. Dalam : Waspadji S, Gani RA, Setiati S, Alwi I, penyunting. Bunga rampai ilmu penyakit dalam. Jakarta : Balai Penerbit FKUI, 1996; h.303-9.

10. Rubin FA. Advances in the diagnosis of typhoid fever using DNA probes. Dalam : Nelwan RHH, penyunting. Typhoid fever : profil, diagnosis and treatment in 1990's. Jakarta : Balai Penerbit FKUI, 1992;h.17-26.

11. Hayani KC, Pickering LK. Salmonella infection. Dalam: Feigin RD, Cherry JD, penyunting. Texbook of pediatric infectious diseases; edisi ke-3. Philadelphia : Saunders, 1992;620-36.

12. Sarasombath S. Immune responses in Typhoid fever. Dalam : Pang T, Koh CL, Puthucheary SD, penyunting. Typhoid fever strategies for the 90's. Singapore : World scientific, 1991;h.168-75.

13. Hoffman SL. Typhoid fever. Dalam : Strickland GT , penyunting. Hunter's textbook of pediatrics; edisi ke-7. Philadelphia : Saunders, 1991;344-58.

14. Gilman RH, Terminel M, Levine MM, Mendoza PB, Hornick RB. Relative efficacy of blood, urine, rectal swab, bone marrow and rose spot cultures for recovery of Salmonella typhi in typhoid fever. Lancet 1975; 31:1211-3.

15. Kresno SB. Diagnosis dan prosedur laboratorium; edisi ke-2. Jakarta : Balai Penerbit FKUI, 1991;h.158-75.

16. Hardi S, Soeharyo, Karnadi E. The diagnostic value of the widal test in typhoid fever patients. Dalam : Nelwan RHH, penyunting. Typhoid fever : profil, diagnosis and treatment in the 1990's. Jakarta : Balai Penerbit FKUI, 1992; h.187-96.

17. Sarasombath S, Ekpo P, Sukosol T, et al. Salmonella flagella : its significance in diagnosis. Dalam : Sarasombath S, Senawong S, penyuning. Second Asia Pasific symposium on typhoid fever and other salmonellosis. Thailand: SEAMEO Regional tropical Medicine and Public Health Network, 1995;209-12.

18. Ismail A, Kader ZK, Ong KH. Dot enzyme immunosorbent assay for the serodiagnosis of typhoid fever. South Asean J Trop Med Public Health 1991;h.22:563-6.

19. Ong KH, Ismail A, Kader ZK, Choo KE. Clinical field trials on the dot enzyme immunosorbent assay for the diagnosis of typhoid fever. Dalam : Pang T, Koh CL, Puthucheary SD, penyunting. Typhoid fever strategies for the 90,s. Singapore: World scientific,1991;h.207-16

20. Lucky H, bella B, Sudarmono P. Study of spesific protein of Salmonela typhi for diagnosis of typhoid fever. Dalam : Sarasombath S, Senawang S, penyunting. Second AsiaPasific Symposium on typhoid fever and othjer Salmonelosis. Thailand: Pang T, Koh CL, Puthucheary $\mathrm{SD}$, penyunting. Typhoid fever strategies for the 90's. Singapore : World scientific, 1991;h.221-6. 
Sari Pediatri, Vol. 2, No. 2, Agustus 2000

21. Wong YH, Jegathesan M, Lim PL. Latex agglutination as a possible aid to the rapid identification of Salmonella group D organism from clinical spesimens. Dalam: Pang T, Koh CL, Puthucheary SD, penyunting. Typhoid fever strategies for the 90's. Singapore: World scientific, 1991;221-6.

22. Chaicumpa W, Ruangkunapon Y, Bur D, et al. Diagnosis of typhoid fever by detection of S.typhi antigen in urine. J Clin Microbiol 1992;30:2513-5.

23. Sadallah F, Brighouse G, Giadice D, et al. Production of spesific monoclonal antiboies to S.typhi flagellin and possible application to immunodiagnosis of typhoid fever. J Infect Dis 1990; 161:59-64.

24. Handojo I. Diagnosis laboratorium demam tifoid. Jurnal Kimia Klinik Indonesia 1996; 73:117-22.

25. Song JH, Cho H, Pank MY, Na DS, Moon HB, Pai $\mathrm{CH}$. Detection of Salmonela typhi in the blood of patients with typhoid fever by Polymerase Chain Reaction. J Clin Microb 1993;3:1439-43. 